Article

\title{
Thermophysical Properties of Newly Synthesized Ammonium-Based Protic Ionic Liquids: Effect of Temperature, Anion and Alkyl Chain Length
}

\author{
Nur Hidayah Zulaikha Othman Zailani ${ }^{1}{ }^{D}$, Normawati M. Yunus ${ }^{1, *(D)}$, \\ Asyraf Hanim Ab Rahim ${ }^{1}$ and Mohamad Azmi Bustam ${ }^{2}$ (D) \\ 1 Department of Fundamental and Applied Sciences, Center of Research in Ionic Liquids (CORIL), \\ Institute of Contaminant Management for Oil and Gas, Universiti Teknologi PETRONAS, \\ Seri Iskandar 32610, Malaysia; zulaikha95.nhz@gmail.com (N.H.Z.O.Z.); \\ asyrafhanim92@gmail.com (A.H.A.R.) \\ 2 Department of Chemical Engineering, Center of Research in Ionic Liquids (CORIL), \\ Institute of Contaminant Management for Oil and Gas, Universiti Teknologi PETRONAS, \\ Seri Iskandar 32610, Malaysia; azmibustam@utp.edu.my \\ * Correspondence: normaw@utp.edu.my; Tel.: +605-368-7689
}

Received: 17 May 2020; Accepted: 21 June 2020; Published: 25 June 2020

\begin{abstract}
Ionic liquids which are often classified as low melting point salts have received significant attention from research groups and industries to be used in a wide range of applications. Many of these applications require thorough knowledge on the thermophysical properties of the ionic liquids before utilizing their full potentials in various fields. In this work, a series of alkylammonium cation and carboxylate anion-based room temperature protic ionic liquids (PILs) were synthesized by varying length of alkyl chain of the cation from diethyl to dibutyl combined with pentanoate, hexanoate and heptanoate anions. These ammonium-based PILs named as diethylammonium pentanoate [DEA][C5], diethylammonium hexanoate [DEA][C6], diethylammonium heptanoate [DEA][C7], dibutylammonium pentanoate [DBA][C5], dibutylammonium hexanoate [DBA][C6] and dibutylammonium heptanoate [DBA][C7] were characterized using Nuclear Magnetic Resonance (NMR) spectroscopy. The thermophysical properties of the PILs namely density, dynamic viscosity and refractive index were measured and analyzed. Density, $\rho$ and dynamic viscosity, $\eta$ were determined at $\mathrm{T}=(293.15$ to 363.15$) \mathrm{K}$ and refractive index, $n_{\mathrm{D}}$ was measured at $\mathrm{T}=(293.15$ to 333.15$) \mathrm{K}$. The fitting parameters are proposed for the empirical correlations of density, dynamic viscosity and refractive index. The values of thermal expansion coefficient, $\alpha_{\mathrm{p}}$, molecular volume, $\mathrm{V}_{\mathrm{m}}$, standard entropy, $\mathrm{S}^{\circ}$ and lattice potential energy, $U_{\text {pot }}$ also have been calculated by using the specified equations. The thermal decomposition temperature, $\mathrm{T}_{\mathrm{d}}$ was also determined using a thermogravimetric analyzer (TGA) while the differential scanning calorimetry (DSC) technique provided the glass transition, $T_{g}$, melting point, $\mathrm{T}_{\mathrm{m}}$ and crystallization, $\mathrm{T}_{\mathrm{c}}$ temperatures of the PILs. The experimental results revealed that the dependency of the experimental values namely the $\rho, \eta, n_{\mathrm{D}}$, and $\mathrm{T}_{\mathrm{d}}$ on the alkyl chain of the anion, size of the cations and the temperature of measurement.
\end{abstract}

Keywords: protic ionic liquids; density; viscosity; refractive index; phase transition; thermal expansion coefficient; standard entropy; lattice potential energy

\section{Introduction}

Ionic liquids (ILs) are molten salts generally made from large organic cations and organic or inorganic anions. These ions interact poorly with each other which causes the salts to exist in liquid forms at room temperature or below $100{ }^{\circ} \mathrm{C}$. ILs possess unique properties such as low 
flammability, high specific solubility, wide liquid range, high electrical conductivity and good thermal and chemical stability [1-5]. These attractive properties have driven researchers to utilize ILs, particularly imidazolium-based ILs, as alternative solvents in various applications such as in membrane separation, gas absorption and organic reactions [6-10]. Recently, protic ionic liquids (PILs) have emerged as promising candidates of alternative solvents due of their low cost of production and a simple one-step synthesis procedure. Besides that, over the past few years, PILs have attracted greater attention from researchers and quite a few works have been done to reveal several potential applications using PILs. Since PILs can be synthesized by the transfer of protons from Brønsted acids to Brønsted bases, PILs can be useful solvents for acid catalyzed reactions such as Diels-Alder reaction [11-13]. Besides that, the presence of active protons in PILs will allow PILs to be suitable electrolytes in fuel cells [14-16]. In addition, PILs are generally more hydrophilic and able to dissolve metals to larger extents than counter aprotic ionic liquids, AILs [14,17]. Ohno and co-workers provided the description of the modern type of protic ionic liquids [18] while Greaves and Drummond wrote an extensive review on the properties and applications of protic ionic liquids [19]. Furthermore, the ionicity of protic ionic liquids is of particular interest due to the possibility of incomplete proton transfer between the acid and base which may contribute to the presence of a neutral acid and base mixture $[17,19,20]$. A limit of $1 \%$ neutral species presence in an ionic liquid was proposed for the acid-base neutralization product to be called 'pure ionic liquid' [21]. Nevertheless, in recent years, ammonium-based PILs have been widely synthesized and used in a wide range of research's applications such as in organic synthesis, oxygen reduction reaction, polymer dissolution, $\mathrm{CO}_{2}$ absorption and separation processes [22-27]. In view of this, proper designing of new PILs, whether by tuning the combination or structures of cations and anions or introducing some special functional groups, is very essential to ensure the PILs meet the standard requirement and physiochemical properties needed by the applications. Furthermore, the measurement of relevant physical properties within the ILs area is one of the most outstanding fields of study as understanding the thermophysical properties of pure ILs and their mixtures in the wide pressure and temperature ranges is essential to determine their potential applications [28]. For example, experimental density, viscosity, and their derived property such as molar volume data of ILs may be of great information in mass and heat transfer processes of working fluids [29]. Therefore, there is a need for systematic thermodynamic and thermophysical measurements for ILs to highlight their availability for use at the industrial processes level. Furthermore, these experimental thermophysical properties of ILs would allow the improvement of overall quality and reliability of the ILs in any applications [30].

This work is a continuation of our previous work to produce ammonium-based PILs as solvents for $\mathrm{CO}_{2}$ absorption. The interest rises from the fact that this type of PILs has demonstrated promising ability to absorb $\mathrm{CO}_{2}$ under experimental conditions, in addition to their simple synthesis procedure i.e., a one-step neutralization reaction [22,31,32]. On different note, this type of PILs may find applications in the areas of lubrication and lead-acid battery modification [33,34]. Previously, we have reported the synthesis, characterization, thermophysical properties and $\mathrm{CO}_{2}$ absorption of ammonium-based PILs utilizing bis (2-ethylhexyl) ammonium, tributylammonium and ethanolammonium cations with acetate and butyrate anions [22]. The results of the work have motivated us to further explore the synthesis and $\mathrm{CO}_{2}$ absorption of ammonium-based PILs by using systematic combinations of simple amines and carboxylic acids. In this work, we report the synthesis of six new ammonium-based PILs, namely diethylammonium pentanoate [DEA][C5], diethylammonium hexanoate [DEA][C6], diethylammonium heptanoate [DEA][C7], dibutylammonium pentanoate [DBA][C5], dibutylammonium hexanoate [DBA][C6] and dibutylammonium heptanoate [DBA][C7] using one-step neutralization reaction as available in literature $[35,36]$. The purity of all these new ammonium-based PILs were checked by ${ }^{1} \mathrm{H}$ and ${ }^{13} \mathrm{C}$ NMR. The water content of these PILs was determined prior studying various thermophysical properties. The thermophysical properties namely density, viscosity and refractive index were measured and discussed in this study. The thermal decomposition, glass transition, crystallization and melting point temperatures of the new ammonium-based PILs were determined. The important 
parameters such as molecular volume, standard molar entropy and lattice energy were estimated by empirical equations. Further, the experimental values of density, viscosity and refractive index analysis were fitted using several empirical equations.

\section{Materials and Methods}

\subsection{Chemicals}

All six ammonium-based PILs were synthesized using two amines and three organic acids from Merck, Darmstadt, Germany. All chemicals with analytical grade were used in this work. The amines and acids CAS numbers, abbreviations and grade percentage are as follows: diethylamine (109-89-7, 99.0\%), dibutylamine (111-92-2, 99.0\%), pentanoic acid (109-52-4, 98.0\%), hexanoic acid (142-62-1, 98.0\%) and heptanoic acid (111-14-8, 99.0\%).

\subsection{Synthesis of PILs}

The PILs were synthesized using a 1-step neutralization reaction. An equimolar amount of acid was added to an equimolar amount of base in 1:1 mol ratio. The organic acids were added dropwise to the flask under stirring with a magnetic bar. The mixtures were constantly stirred for $24 \mathrm{~h}$ at room temperature. In order to remove traces of water that might be coming from surrounding atmosphere or from the starting reagents, the synthesized PILs were heated at $70^{\circ} \mathrm{C}$ under vacuum approximately for $8 \mathrm{~h}$ upon the completion of the reaction [35]. The dried samples were sealed and kept until further analysis. There was no noticeable solid crystal or precipitation formed when the PILs were purified after synthesis [36]. The proton transfer reaction results in carboxylate salt namely pentanoate, hexanoate and heptanoate of diethyl or dibutylamine. Generally, the reaction can be expressed as follows:

$$
\left(\mathrm{R}_{\mathrm{x}}\right)_{2} \mathrm{NH}+\mathrm{HOOC}\left(\mathrm{R}_{\mathrm{Y}}\right) \rightarrow\left(\mathrm{R}_{\mathrm{x}}\right)_{2} \mathrm{NH}_{2}{ }^{+-} \mathrm{OOC}\left(\mathrm{R}_{\mathrm{Y}}\right)
$$

where $R_{X}$ is the alkyl substitutions into the amine compound (ethyl or butyl). Meanwhile, $R_{Y}$ is the alkyl substitution into the acid compound (pentyl, hexyl or heptyl). For example, diethylammonium pentanoate is formed when $R_{X}$ is ethyl and $R_{Y}$ is pentyl. In this work, diethylamine [DEA] and dibutylamine [DBA] were used as the sources of the cations while carboxylate acids with alkyl chain length of pentyl, [C5], hexyl, [C6] and heptyl [C7] were utilized to provide the anions of the PILs. The combinations of the acids and the amines resulted in six PILs as tabulated in Table 1.

\subsection{Structural Characterization and Water Content}

The structural confirmation of the PILs was done by using Nuclear Magnetic Resonance (NMR) spectroscopy (Bruker, Billerica, MA, USA). In this work, $100 \mu \mathrm{L}$ sample was dissolved in $600 \mu \mathrm{L}$ solvent $\left(\mathrm{CDCl}_{3}\right)$ for each analysis. Both ${ }^{1} \mathrm{H}$ and ${ }^{13} \mathrm{C}$ spectra were recorded using Bruker Ascend TM 500 from Bruker, Billerica, MA, USA. The spectra are reported in parts per million and the multiplicities are abbreviated as $s$ (singlet), $d$ (doublet), $t$ (triplet) and $m$ (multiplet). Meanwhile, Volumetric Karl Fisher and Stromboli Oven (Model: V30 Mettler Toledo, Columbus, OH, USA) was used to analyze the water content in the synthesized PILs.

\subsection{Thermophysical Properties Characterization}

The density and viscosity of PILs were measured simultaneously via scanning preset at temperatures from 293.15 to $363.15 \mathrm{~K}$ using Anton Paar Stabinger Viscometer SVM3000 (Graz, Austria). The measurements were done in three replications and the average value was taken for further study. The viscometer was calibrated using a standard fluid provided by the supplier and a validation test was also conducted using a commercial imidazolium IL with known density and viscosity values.

The refractive index values of the PILs were determined using ATAGO RX-5000 Alpha Digital Refractometer from Tokyo, Japan in the temperature range of 293.15 to $333.15 \mathrm{~K}$. Several standard 
organic solvents provided by the supplier were used to calibrate the instrument. A validation test was also conducted using a commercial imidazolium IL and the result was compared with the values available from literatures.

The decomposition temperatures of the PILs were determined by using thermogravimetric analyzer (TGA) (Simultaneous Thermal Analyer (STA) 6000 from Perkin Elmer, Walthan, Massachusetts, United States). In this study, Simultaneous Thermal Analyzer (STA) 6000 from Perkin Elmer (Waltham, MA, USA) was used to complete the thermal stability analysis. An approximate $10 \mathrm{mg}$ of sample was weighted in a crucible pan and the analysis was performed in the temperature range of $30-650{ }^{\circ} \mathrm{C}$ under $20 \mathrm{~mL} / \mathrm{min}$ nitrogen flow with a heating rate of $10^{\circ} \mathrm{C} \cdot \mathrm{min}^{-1}$.

The phase transition and melting point analyses were carried out by using Differential Scanning Calorimeter (DSC) 1 Star system, Mettler Toledo (Columbus, OH, USA). About $10 \mathrm{mg}$ of samples was weighted in aluminum pans and sealed. The reaction was conducted in the temperature range of 80 to $-150{ }^{\circ} \mathrm{C}$ with a heating rate of $10^{\circ} \mathrm{C} \cdot \mathrm{min}^{-1}$. The data were collected in the second cooling plot.

Table 1. List of acids, bases and new ammonium-based protic ionic liquids (PILs) synthesized in this work.

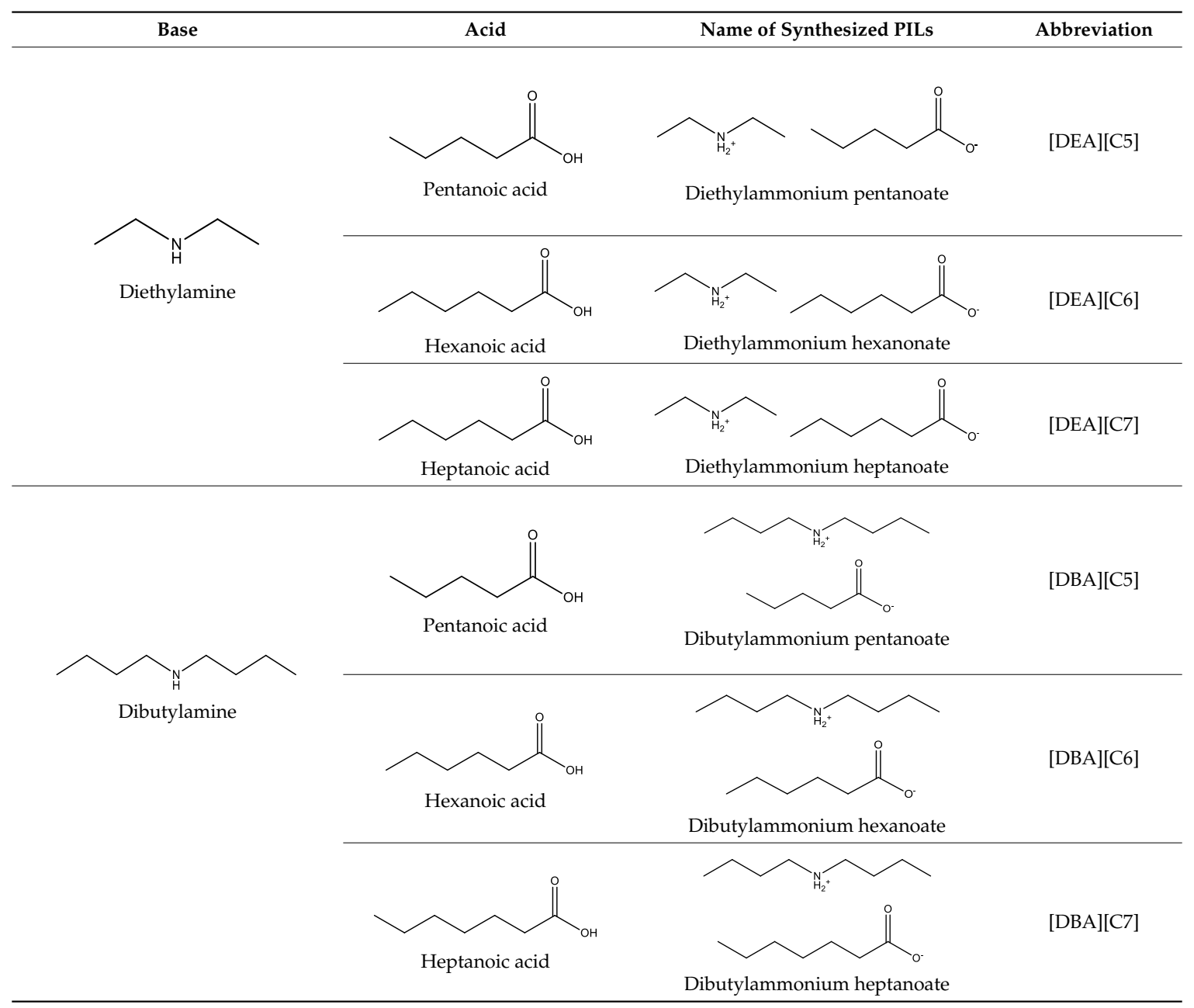

\section{Results and Discussion}

\subsection{Structural Characterization and Water Content Analysis}

All six ammonium-based PILs synthesized in this work exist as liquids at room temperature. The NMR and water content results of each of these six ammonium-based PILs; diethylammonium pentanoate [DEA][C5], diethylammonium hexanoate [DEA][C6], diethylammonium heptanoate 
[DEA][C7], dibutylammonium pentanoate [DBA][C5], dibutylammonium hexanoate [DEA][C6] and dibutylammonium heptanoate [DBA][C7] are presented accordingly as follows as well as in the Figures S1-S12 in the Supplementary Materials:

[DEA][C5]: ${ }^{1} \mathrm{H}$ NMR (500 MHz, $\left.\mathrm{CDCl}_{3}\right): \delta 0.86\left[\mathrm{t}, 3 \mathrm{H}\left(\mathrm{R}_{-} \mathrm{CH}_{3}\right)\right], \delta 1.29\left[\mathrm{~m}, 8 \mathrm{H}\left(\mathrm{R}_{-}-\mathrm{CH}_{3}, \mathrm{R}_{-} \mathrm{CH}_{2}\right), \delta 1.51\right.$ $\left[\mathrm{m}, 2 \mathrm{H}\left(\mathrm{R}-\mathrm{CH}_{2}\right)\right], \delta 2.19\left(\mathrm{t}, 2 \mathrm{H}\left(\mathrm{COOH}-\mathrm{CH}_{2}\right)\right], \delta 2.89\left[\mathrm{~m}, 4 \mathrm{H}\left(\mathrm{NH}_{2}-\mathrm{CH}_{2}\right)\right] .{ }^{13} \mathrm{C} \mathrm{NMR}\left(125 \mathrm{MHz}, \mathrm{CDCl}_{3}\right)$ : $\delta 179.43,41.94,35.47,27.60,22.38,13.73,11.10$. Water content: $0.93 \%$.

[DEA][C6]: ${ }^{1} \mathrm{H}$ NMR $\left(500 \mathrm{MHz}, \mathrm{CDCl}_{3}\right): \delta 0.88$ [t, 3H $\left.\left(\mathrm{R}_{-}-\mathrm{CH}_{3}\right)\right], 1.29$ [m, $\left.8 \mathrm{H}\left(\mathrm{R}-\mathrm{CH}_{3}, \mathrm{R}_{-} \mathrm{CH}_{2}\right)\right], 1.58$ [m, $\left.4 \mathrm{H}\left(\mathrm{R}-\mathrm{CH}_{2}\right)\right], 2.19$ [t, $\left.2 \mathrm{H}\left(\mathrm{COOH}-\mathrm{CH}_{2}\right)\right], 2.89\left[\mathrm{~m}, 4 \mathrm{H}\left(\mathrm{NH}_{2}-\mathrm{CH}_{2}\right)\right] .{ }^{13} \mathrm{C} \mathrm{NMR}\left(125 \mathrm{MHz}, \mathrm{CDCl}_{3}\right): \delta$ $180.14,41.76,37.27,31.78,25.92,22.49,13.98,11.24$. Water content: $6.45 \%$.

[DEA][C7]: ${ }^{1} \mathrm{H}$ NMR $\left(500 \mathrm{MHz}, \mathrm{CDCl}_{3}\right): \delta 0.87$ [t, 3H $\left.\left(\mathrm{R}_{-}-\mathrm{CH}_{3}\right)\right], 1.27\left[\mathrm{~m}, 8 \mathrm{H}\left(\mathrm{R}^{-\mathrm{CH}_{3},} \mathrm{R}_{-}-\mathrm{CH}_{2}\right)\right], 1.58$ [m, $\left.6 \mathrm{H}\left(\mathrm{R}_{-} \mathrm{CH}_{2}\right)\right], 2.22\left[\mathrm{t}, 2 \mathrm{H}\left(\mathrm{COOH}-\mathrm{CH}_{2}\right)\right], 2.92\left[\mathrm{~m}, 4 \mathrm{H}\left(\mathrm{NH}_{2}-\mathrm{CH}_{2}\right)\right] .{ }^{13} \mathrm{C} \mathrm{NMR}\left(125 \mathrm{MHz}, \mathrm{CDCl}_{3}\right): \delta$ $180.16,41.77,37.38,31.69,29.26,26.24,22.56,14.02,11.26$. Water content: $3.43 \%$.

[DBA][C5]: ${ }^{1} \mathrm{H}$ NMR $\left(500 \mathrm{MHz}, \mathrm{CDCl}_{3}\right): \delta 0.847\left[\mathrm{~m}, 9 \mathrm{H}\left(-\mathrm{CH}_{3}\right)\right], 1.28\left[\mathrm{~m}, 6 \mathrm{H}\left(-\mathrm{CH}_{2},-\mathrm{CH}_{3}\right)\right], 1.478$ [m, $\left.2 \mathrm{H}\left(-\mathrm{CH}_{2}\right)\right], 1.609$ [m, 4H (-CH $)$ ], $2.106\left[\mathrm{t}, 2 \mathrm{H}\left(\mathrm{CH}_{2}-\mathrm{COO}-\right)\right], 2.721$ [t, $\left.4 \mathrm{H}\left(\mathrm{CH}_{2}-\mathrm{NH}\right)\right] .{ }^{13} \mathrm{C} \mathrm{NMR}(125$ $\left.\mathrm{MHz}, \mathrm{CDCl}_{3}\right): \delta 180.16,47.36,37.65,28.69,28.24,22.70,20.12,13.92,13.58$. Water content: $5.70 \%$.

[DBA][C6]: ${ }^{1} \mathrm{H}$ NMR $\left(500 \mathrm{MHz}, \mathrm{CDCl}_{3}\right): \delta 0.846\left[\mathrm{~m}, 9 \mathrm{H}\left(-\mathrm{CH}_{3}\right)\right], 1.289\left[\mathrm{~m}, 8 \mathrm{H}\left(-\mathrm{CH}_{2},-\mathrm{CH}_{3}\right)\right], 1.511$ [m, $\left.\left.\left.2 \mathrm{H}\left(-\mathrm{CH}_{2}\right)\right], 1.615\left[\mathrm{~m}, 4 \mathrm{H}\left(-\mathrm{CH}_{2}\right)\right], 2.095\left[\mathrm{t}, 2 \mathrm{H}\left(\mathrm{CH}_{2}-\mathrm{COO}-\right)\right], 2.724\left[\mathrm{t}, 4 \mathrm{H}\left(\mathrm{CH}_{2}-\mathrm{NH}\right)\right].\right)\right] .{ }^{13} \mathrm{C} \mathrm{NMR}(125$ $\left.\mathrm{MHz}, \mathrm{CDCl}_{3}\right): \delta 180.11,47.33,37.92,31.86,28.21,26.22,22.52,20.09,13.93,13.54$. Water content: $5.56 \%$.

[DBA][C7]: ${ }^{1} \mathrm{H}$ NMR $\left(500 \mathrm{MHz}, \mathrm{CDCl}_{3}\right): \delta 0.800\left[\mathrm{~m}, 9 \mathrm{H}\left(-\mathrm{CH}_{3}\right)\right], 1.275\left[\mathrm{~m}, 10 \mathrm{H}\left(-\mathrm{CH}_{2},-\mathrm{CH}_{3}\right)\right], 1.501$ [m, 2H (- $\left.\left.\mathrm{CH}_{2}\right)\right], 1.067$ [m, 4H (- $\left.\left.\mathrm{CH}_{2}\right)\right], 2.110\left[\mathrm{t}, 2 \mathrm{H}\left(\mathrm{CH}_{2}-\mathrm{COO}-\right)\right], 2.721$ [t, 4H $\left.\left.\left.\left(\mathrm{CH}_{2}-\mathrm{NH}\right)\right].\right)\right] .{ }^{13} \mathrm{C} \mathrm{NMR}$ $\left(125 \mathrm{MHz}, \mathrm{CDCl}_{3}\right): \delta 180.19,47.39,37.99,31.76,29.35,28.31,26.52,22.55,20.13,13.99,13.58$. Water content: $4.39 \%$.

Six protic ionic liquids with the ammonium cation, [DEA] and [DBA], were synthesized through acid-base neutralization reactions with different alkyl chain length of ammonium-based cation and the corresponding organic acid. The reported water content is between $0.93 \%$ and $6.45 \%$ for the synthesized PILs. The water traces may come from the starting materials or from surrounding atmosphere during the synthesis process [35]. Besides, Chen and his team conducted investigations on water sorption in PILs at ambient environment and revealed that PILs are highly hygroscopic and have higher hydrophilicity compared to aprotic ionic liquids [37]. Meanwhile, other researchers concluded that the anion was the key factor influencing water sorption [38]. Furthermore, several researchers indicate that the presence of water molecules reduces the electrostatic attractions between the ions and consequently lowers the viscosity of ILs as the overall cohesive energy of the system is decreased [39]. Nevertheless, the thermophysical properties of our ammonium-based PILs are solely reported by using these water contents.

\subsection{Thermophysical Properties Analysis}

All instruments used for measuring the density, viscosity and refractive index were calibrated using standard solutions provided by the supplier. In addition, a commercial IL namely 1-hexyl-3-methylimidazolium bis(trifluoromethylsulfonyl)imide [HMIM][Tf 2 N], (Merck, 382150-50-7, 98\%) with readily available physical property data was tested using these instruments so as to validate the experimental data. From the measurements, the experimental values of density, viscosity and refractive index at $298.15 \mathrm{~K}$ displayed a very good agreement with the values from the literatures as shown in Table S1 in the Supplementary Materials. 
The density values of the PILs were recorded as a function of temperature from 293.15 to 363.15 K. The plots of the experimental density of PILs are shown in Figure 1 and the experimental data is available Table S2 in the Supplementary Materials. Generally, based on the results, the densities for all six ammonium-based PILs decreased linearly as the temperature increased despite the difference in the alkyl length of the anions. At higher temperatures, the intermolecular forces between the constituted ions are weakened and therefore increased the mobility of the ions. Consequently, the unit volume for these ions increased as well $[22,40,41]$. On the other hand, from the experimental results, [DEA][C5] has the highest density values compared to the rest of ammonium-based PILs. This observation can be explained by the change of local packing of the PIL structure due to the smaller size of the [DEA] cation, in comparison to [DBA] cation [22,42]. Several researchers reported the similar behavior using other PIL with ethylammonium cation, which increasing trending packing efficiency with the decreasing of molecular weight [43]. Other than that, [DBA][C7] showed the lowest density value at all temperatures. As the alkyl chain increases in both cation and anion of the PIL, the structure gets bigger and bulkier which in turn promoting steric hindrance and asymmetric nature in the PIL structure and thus result in a lower density value for the PIL [41,42].

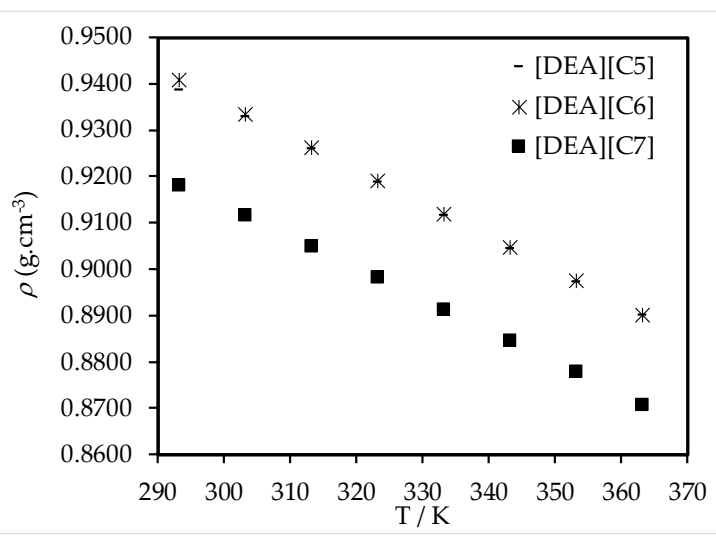

(a)

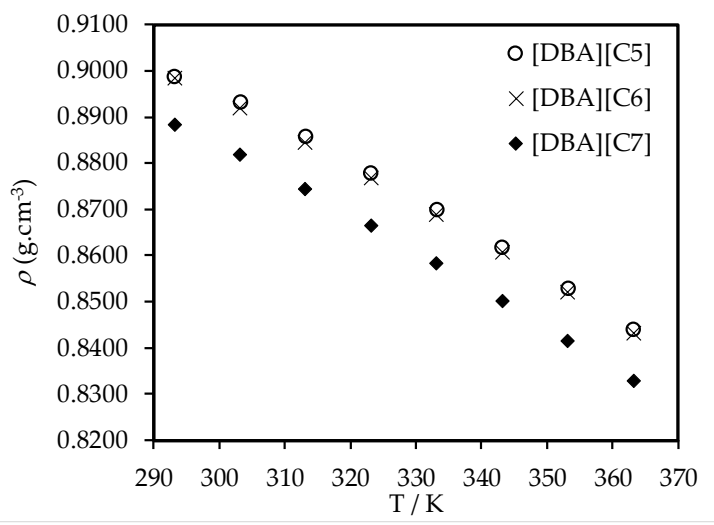

(b)

Figure 1. (a) Density $(\rho)$ values of diethylammonium pentanoate [DEA][C5], diethylammonium hexanoate [DEA][C6], and diethylammonium heptanoate [DEA][C7] as a function of temperature. (b) Density $(\rho)$ values of dibutylammonium pentanoate [DBA][C5], dibutylammonium hexanoate $[\mathrm{DEA}][\mathrm{C} 6]$ and dibutylammonium heptanoate [DBA][C7] as a function of temperature.

Viscosity is a key parameter that helps to designate the potential applications of any ILs and it is greatly influenced by intermolecular interactions namely hydrogen bonding, dispersive forces and columbic interactions [44]. Figure 2 and Table S3 in the Supplementary Materials show the dynamic viscosity data of the ammonium-based PILs which have been measured in the temperature range of 293.15 to $363.15 \mathrm{~K}$.

From Figure 2, analysis of the results revealed that the viscosity of all ammonium-based PILs decreased exponentially with increasing temperature in the range of temperature studied. It was found that the PILs with [DBA] cation display higher viscosity value than PILs with [DEA] cation. The increase of viscosity with increasing alkyl chain length in the ILs structure is due to the increase in van der Waals attraction between the aliphatic alkyl chain [40,45]. PILs with [DBA] cation, however show marginal increment in the viscosity values as the anion alkyl chain increases. Nevertheless, the increment of alkyl chain length on anion structure depicted the same trend for both [DEA] and [DBA] cation as the viscosity is increasing in the order of [C5] $<[\mathrm{C} 6]<[\mathrm{C} 7]$. On the other hand, Iglesias et al., investigated the viscosity of 2-hydroxy ethylammonium propionate (2-HEAPE), 2-hydroxy diethylammonium propionate (2-HDEAPE) and 2-hydroxy triethylammonium propionate (2-HTEAPE) and found that the viscosity value decreases with the increasing number of ethyl group at the cation [36]. 
This behavior might be affected by the increase of the cation structure due to the replacement of hydrogen atoms with an ethyl group.

The refractive index, $n_{\mathrm{D}}$ estimates the electronic polarizability of the molecules and shows the dielectric response to an external electric field produced by electromagnetic waves (light) [46]. Generally, it describes how fast light travels through the material. The refractive index of ammonium-based PILs was measured at temperatures of 293.15 to $333.15 \mathrm{~K}$ and the experimental data is available in Table $S 4$ in the Supplementary Materials. The $n_{D}$ decreased in a very narrow window with increasing of temperature as shown in Figure 3. On the other hand, the values of refractive index increased with the increase in cation and anion chain length of PILs. The increment of the refractive index in line with the increment of the alkyl chain in the PILs structures is believed to occur due to the influence of higher intermolecular interaction such as the van der Waals forces of the PILs [41].

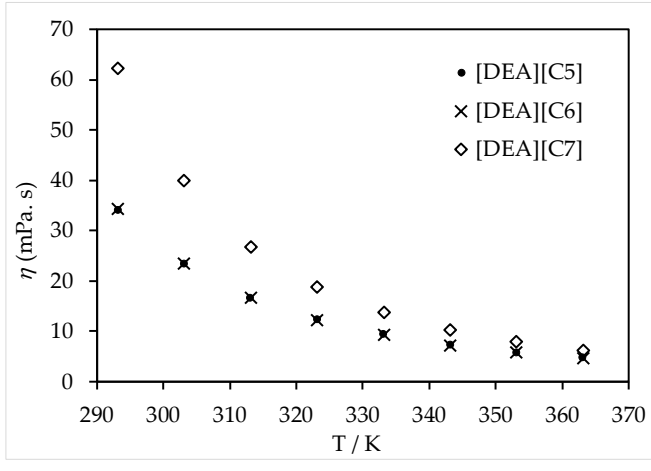

(a)

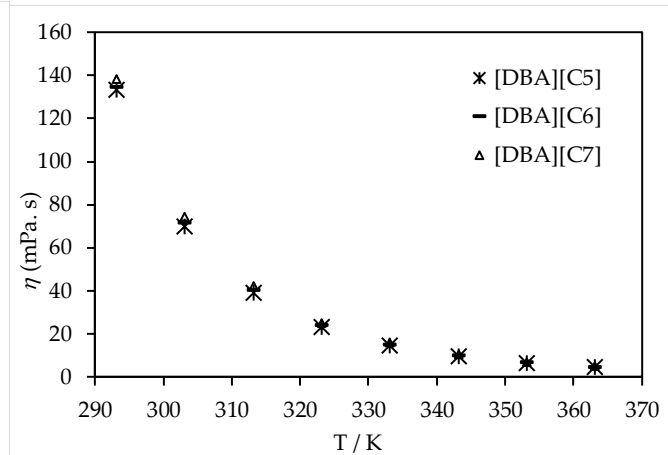

(b)

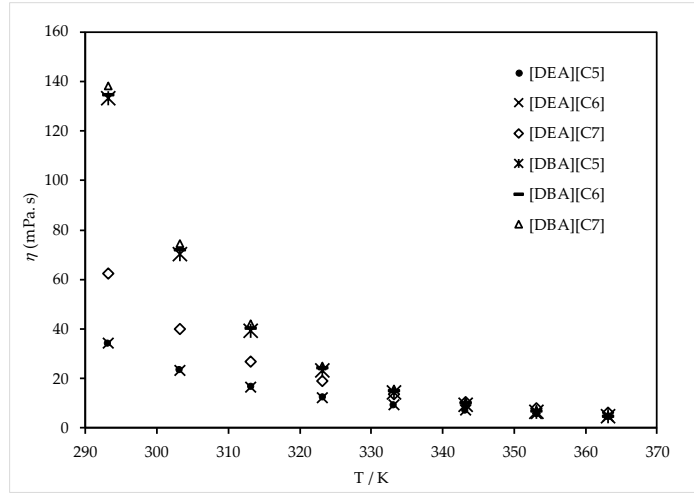

(c)

Figure 2. (a) Viscosity $(\eta)$ of [DEA][C5], [DEA][C6] and [DEA][C7] as a function of temperature. (b) Viscosity $(\eta)$ of [DBA][C5], [DBA][C6] and [DBA][C7] as a function of temperature. (c) Viscosity $(\eta)$ of all six ammonium-based PILs as a function of temperature. 


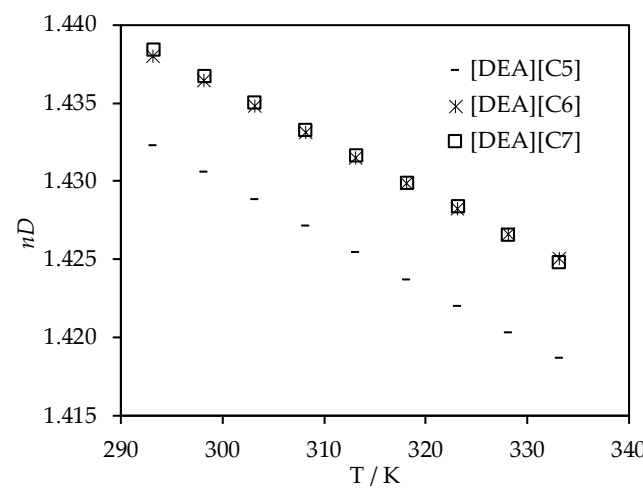

(a)

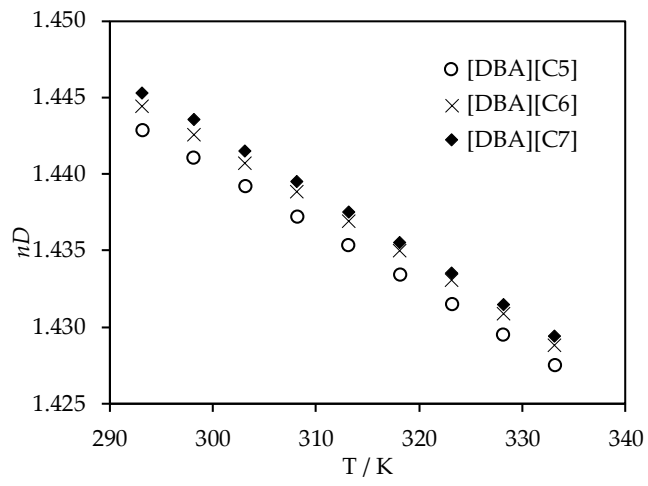

(b)

Figure 3. (a) Refractive index $\left(n_{\mathrm{D}}\right)$ values of [DEA][C5], [DEA][C6] and [DEA][C7] as a function of temperature. (b) Refractive index $\left(n_{\mathrm{D}}\right)$ values of [DBA][C5], [DBA][C6] and [DBA][C7] as a function of temperature.

\subsection{Thermophysical Properties Correlations}

The density, $\rho$ dynamic viscosity, $\eta$ and refractive index, $n_{\mathrm{D}}$ experimental values were fitted using the following equations [40,47]:

$$
\begin{gathered}
\rho=\mathrm{A}_{1}+\mathrm{A}_{2} \mathrm{~T}, \\
\lg \eta=\mathrm{A}_{3}+\mathrm{A}_{4} / \mathrm{T}, \\
n_{\mathrm{D}}=\mathrm{A}_{5}+\mathrm{A}_{6} \mathrm{~T},
\end{gathered}
$$

where $\rho$ is the density, $\eta$ is dynamic viscosity and $n_{\mathrm{D}}$ is refractive index of the ammonium-based PILs, $\mathrm{T}$ is temperature in $\mathrm{K}$, and $\mathrm{A}_{1}$ through $\mathrm{A}_{6}$ are correlation coefficients using the least square method. Tables 2-4 represent the estimation of values of correlation coefficients and the standard deviations, SD calculated using the equation from the literature [40].

Table 2. Fitting parameters of Equation (1) to correlate density $(\rho)$ of synthesized PILs and calculated standard deviation (SD).

\begin{tabular}{cccc}
\hline Ionic Liquids & $\mathbf{A}_{\mathbf{1}}$ & $\mathbf{A}_{\mathbf{2}}$ & $\mathbf{S D}$ \\
\hline$[\mathrm{DEA}][\mathrm{C} 5]$ & 1.1456 & -0.0007 & 0.0010 \\
{$[\mathrm{DEA}][\mathrm{C} 6]$} & 1.1519 & -0.0007 & 0.0068 \\
{$[\mathrm{DEA}][\mathrm{C} 7]$} & 1.1168 & -0.0007 & 0.0076 \\
{$[\mathrm{DBA}][\mathrm{C} 5]$} & 1.1331 & -0.0008 & 0.0027 \\
{$[\mathrm{DBA}][\mathrm{C} 6]$} & 1.1345 & -0.0008 & 0.0027 \\
{$[\mathrm{DBA}][\mathrm{C} 7]$} & 1.1269 & -0.0008 & 0.0008 \\
\hline
\end{tabular}

Table 3. Fitting parameters of Equation (2) to correlate viscosity $(\eta)$ of PILs and calculated standard deviation (SD).

\begin{tabular}{cccc}
\hline Ionic Liquid & $\mathbf{A}_{\mathbf{3}}$ & $\mathbf{A}_{\mathbf{4}}$ & $\mathbf{S D}$ \\
\hline$[\mathrm{DEA}][\mathrm{C} 5]$ & -2.9587 & 1312.0 & 0.0106 \\
{$[\mathrm{DEA}][\mathrm{C} 6]$} & -2.9597 & 1312.4 & 0.0108 \\
{$[\mathrm{DEA}][\mathrm{C} 7]$} & -3.4058 & 1518.0 & 0.0133 \\
{$[\mathrm{DBA}][\mathrm{C} 5]$} & -5.4771 & 2219.3 & 0.0207 \\
{$[\mathrm{DBA}][\mathrm{C} 6]$} & -5.4156 & 2203.9 & 0.0179 \\
{$[\mathrm{DBA}][\mathrm{C} 7]$} & -5.3421 & 2186.0 & 0.0176 \\
\hline
\end{tabular}


Table 4. Fitting parameters of Equation (3) to correlate refractive index ( $\left.n_{\mathrm{D}}\right)$ of PILs and calculated standard deviation (SD).

\begin{tabular}{cccc}
\hline Ionic Liquid & $\mathbf{A}_{\mathbf{5}}$ & $\mathbf{A}_{\mathbf{6}}$ & $\mathbf{S D}$ \\
\hline$[\mathrm{DEA}][\mathrm{C} 5]$ & 1.5326 & -0.0003 & 0.0132 \\
{$[\mathrm{DEA}][\mathrm{C} 6]$} & 1.5335 & -0.0003 & 0.0081 \\
{$[\mathrm{DEA}][\mathrm{C} 7]$} & 1.5376 & -0.0003 & 0.0120 \\
{$[\mathrm{DBA}][\mathrm{C} 5]$} & 1.5557 & -0.0004 & 0.0265 \\
{$[\mathrm{DBA}][\mathrm{C} 6]$} & 1.5583 & -0.0004 & 0.0276 \\
{$[\mathrm{DBA}[\mathrm{C}]$} & 1.5623 & -0.0004 & 0.0309 \\
\hline
\end{tabular}

\subsection{Thermal Expansion Coefficient, Standard Entropy, Lattice Potential Energy, Water Content and} Thermal Study

For further understanding of the intermolecular interaction, the thermal expansion coefficient can be calculated from the experimental values of density, $\rho$ and the data is tabulated in Table 5 . Thermal expansion coefficients, $\alpha_{\mathrm{p}}$ for the synthesized PILs can be defined as [22,40,48]:

$$
\alpha_{p}=-1 / \rho .(\delta \rho / \delta \mathrm{T})=-\left(\mathrm{A}_{2}\right) /\left(\mathrm{A}_{1}+\mathrm{A}_{2} \mathrm{~T}\right)
$$

The calculated values in Table 5 show that the thermal expansion coefficients increase with the total C-numbers in the structure of PILs. This indicates that the thermal expansion coefficient is dependent on the cation symmetry and the length of alkyl substituent [49]. In view of the result obtained, thermal expansion coefficients of PILs with [DBA] cation are higher than that of PILs with [DEA] cation. Meanwhile, the behavior of thermal expansion coefficient is almost the same for all PILs with the same cation group in which the calculations show very small deviations of $\alpha_{p}$ values with temperature. Thus, thermal expansion coefficient can be considered as temperature independent as it shows similar result over the temperature range studied. Yunus et al., also reported the similar trend of variation of thermal expansion coefficient for different group of PILs [22].

Molar volume, $\mathrm{V}_{\mathrm{m}}$ can be defined as the volume occupied by one mole of a compound at a given temperature and pressure [50]. The molar volume, $\mathrm{V}_{\mathrm{m}}$ was obtained by the following empirical equation according to the experimental densities [45,51-53]:

$$
\mathrm{V}_{\mathrm{m}}=\mathrm{M} /\left(\rho \cdot \mathrm{N}_{\mathrm{A}}\right) \text {, }
$$

where $V_{m}$ is the molecular volume, $\mathrm{M}$ is molar mass of PILs, $\rho$ is density of PILs at $303.15 \mathrm{~K}$ and $\mathrm{N}_{\mathrm{A}}$ is the Avogadro's number.

Table 5. Thermal expansion coefficients $\left(\alpha_{\mathrm{p}}\right)$ of the PILs calculated using Equation (4).

\begin{tabular}{ccccccc}
\hline \multirow{2}{*}{$\mathbf{T} / \mathbf{K}$} & $\mathbf{1 0}^{\mathbf{- 4}} \boldsymbol{\alpha} / \mathbf{K}^{\mathbf{- 1}}$ & \multicolumn{1}{c}{} & \\
\cline { 2 - 7 } & [DEA][C5] & [DEA][C6] & [DEA][C7] & [DBA][C5] & [DBA][C6] & [DBA][C7] \\
\hline 293.15 & 7.4 & 7.4 & 7.7 & 8.9 & 8.9 & 9.0 \\
303.15 & 7.5 & 7.4 & 7.7 & 9.0 & 9.0 & 9.1 \\
313.15 & 7.6 & 7.5 & 7.8 & 9.1 & 9.1 & 9.2 \\
323.15 & 7.6 & 7.6 & 7.9 & 9.1 & 9.2 & 9.2 \\
333.15 & 7.7 & 7.6 & 7.9 & 9.2 & 9.2 & 9.3 \\
343.15 & 7.7 & 7.7 & 8.0 & 9.3 & 9.3 & 9.4 \\
353.15 & 7.8 & 7.7 & 8.0 & 9.4 & 9.4 & 9.5 \\
363.15 & 7.9 & 7.8 & 8.1 & 9.5 & 9.5 & 9.6 \\
\hline
\end{tabular}

Molar volume for all ammonium-based PILs were calculated at temperature of $303.15 \mathrm{~K}$. As shown in Table 6, the molar volume, $\mathrm{V}_{\mathrm{m}}$ is proportional to the length of the alkyl chain of the anion as well as the size of the cation. The former is caused by the addition of $\mathrm{CH}_{2}$ group in the anion of the 
PILs and similar findings have been observed in other studies, while the latter is due to the bigger size of [DBA] as compared to [DEA] [5,22].

Table 6. Molar volume, $\mathrm{V}_{\mathrm{m}}$; standard entropy, $\mathrm{S}^{\circ}$; lattice potential energy, $\mathrm{U}_{\text {pot }}$; thermal decomposition, $\mathrm{T}_{\mathrm{d}}$; glass transition, $\mathrm{T}_{\mathrm{g}}$; melting point, $\mathrm{T}_{\mathrm{m}}$; crystallization point, $\mathrm{T}_{\mathrm{c}} . \mathrm{V}_{\mathrm{m}}, \mathrm{S}^{\circ}$ and $\mathrm{U}_{\text {pot }}$ were calculated at $303.15 \mathrm{~K}$.

\begin{tabular}{|c|c|c|c|c|c|c|c|}
\hline Ionic Liquids & $\mathbf{V}_{\mathbf{m}}$ & $\mathbf{S}^{\circ}$ & $\mathrm{U}_{\text {pot }}$ & $T_{d}$ & $\mathrm{~T}_{\mathrm{g}}$ & $\mathrm{T}_{\mathrm{m}}$ & $\mathrm{T}_{\mathrm{c}}$ \\
\hline & $\mathrm{nm}^{3}$ & $\mathrm{~J} \cdot \mathrm{K}^{-1} \cdot \mathrm{mol}^{-1}$ & $\mathrm{~kJ} \cdot \mathrm{mol}^{-1}$ & $\mathbf{K}$ & ${ }^{\circ} \mathrm{C}$ & ${ }^{\circ} \mathrm{C}$ & ${ }^{\circ} \mathrm{C}$ \\
\hline [DEA][C5] & 0.3120 & 418.4 & 449.8 & 412.82 & -100.4 & -9.7 & -58.8 \\
\hline [DEA][C7] & 0.3704 & 491.2 & 430.6 & 442.00 & -99.6 & 0.8 & -60.2 \\
\hline [DBA][C5] & 0.4302 & 565.8 & 414.7 & 404.78 & - & -20.9 & - \\
\hline [DBA][C6] & 0.4570 & 599.1 & 408.5 & 425.33 & - & -12.8 & - \\
\hline
\end{tabular}

Entropy is the measurement of randomness of molecules. Generally, entropy increases with the increase in molar volume [5]. In order to study the relationship between molecular volume and standard entropy for both ionic liquids and organic acids, Glasser [54] had provided a standard equation as follows:

$$
\mathrm{S}^{\circ}=1246.5 \mathrm{~V}_{\mathrm{m}}+29.5
$$

in which $\mathrm{V}_{\mathrm{m}}$ is the molecular volume in $\mathrm{nm}^{3}$ and $\mathrm{S}^{\circ}$ is standard entropy.

The results in Table 6 clearly show that the standard entropy $\left(\mathrm{S}^{\circ}\right)$ of ammonium-based PILs increased with the molar volume for all ammonium-based PILs at the studied temperature. This increment in the $S^{\circ}$ values could be related to increasing the number of carbon atoms in alkyl chain of carboxylate anion [38]. In this work, the $\mathrm{V}_{\mathrm{m}}$ increases in the sequence of [C5] $<$ [C6] $<$ [C7] for both [DEA] and [DBA] cations.

Besides standard entropy, Glasser [54] also proposed a method for calculating lattice potential energies $\left(U_{\text {pot }}\right)$ of ILs in order to predict the relative stabilities of ILs by using Equation (7) where $\gamma$ and $\delta$ are fitting coefficients with values of $1981.9 \mathrm{~kJ} \cdot \mathrm{mol}^{-1}$ and $103.8 \mathrm{~kJ} \cdot \mathrm{mol}^{-1}$, respectively.

$$
\mathrm{U}_{\text {pot }}=\left[\gamma(\rho / \mathrm{M})^{1 / 3}\right]+\delta
$$

There is no obvious influence of structural properties in lattice potential energy. However, electrostatic or columbic interaction is the main factor that contributes to lattice energy which is inversely related to the volume of ions $[5,41,44]$. Table 6 shows the calculated lattice potential energy of the studied PILs at $303.15 \mathrm{~K}$. In this work, we observed that the lattice potential energy decreased with increasing carbon chain length of the carboxylate anions. This can be explained by the fact that adding a methylene group in the alkyl chain of the ammonium-based PILs will increase the entropy and consequently cause a reduction of the packing efficiency in the PILs. Thus, as a result, lattice potential energy will decrease with the increase in the alkyl chain length of the PILs.

The study of thermal analysis of a substance is crucial as it will provide information on how PILs behave as heat flows. The thermal stability of the PIL was examined by thermogravimetric analysis (TGA) and the data are tabulated in Table 6 while TGA profiles are graphically presented in Figure 4. The TGA for studied PILs was performed at scanning rate of $10^{\circ} \mathrm{C} \cdot \mathrm{min}^{-1}$. In the TGA study, the main factor of thermal stability is dependent on the strength of the heteroatom-carbon and heteroatom-hydrogen bond [44]. 


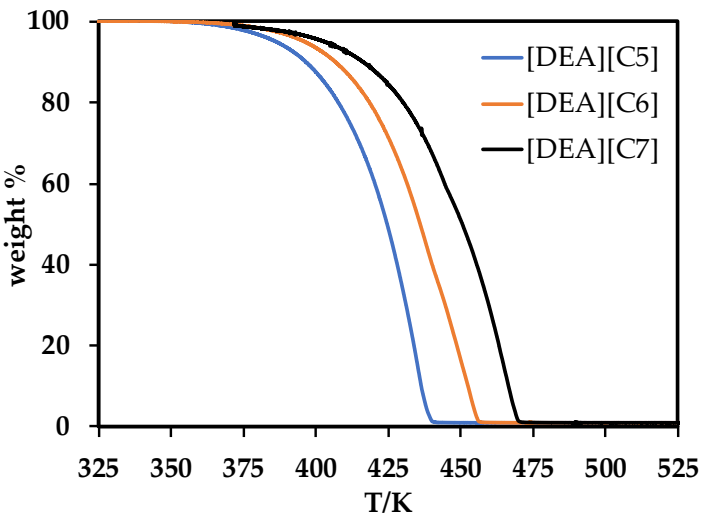

(a)

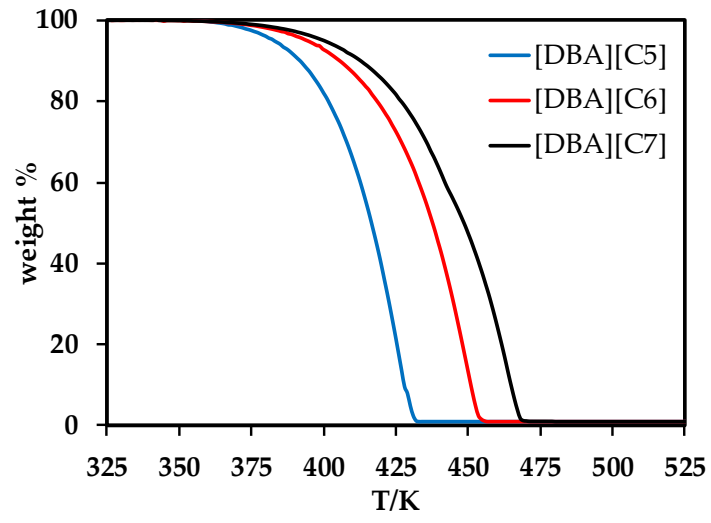

(b)

Figure 4. (a) Thermal decomposition curve of [DEA][C5], [DEA][C6] and [DEA][C7] at a heating rate of $10^{\circ} \mathrm{C} \cdot \mathrm{min}^{-1}$. (b) Thermal decomposition curve of [DBA][C5], [DBA][C6] and [DBA][C7] at a heating rate of $10{ }^{\circ} \mathrm{C} \cdot \mathrm{min}^{-1}$.

The studied PILs showed thermal stabilities in the range of approximately 404 to $442 \mathrm{~K}$. The TGA profiles of the studied PILs indicate a one-step decomposition temperature for all ammonium-based PILs. As can be seen from Figure 4 and Table 6, the thermal decomposition $\left(T_{d}\right)$ increases as the alkyl chain length in anion increases within the same cation and the order of thermal stability of the ammonium-based PILs can be listed as [DEA][C5] $<$ [DEA][C6] $<$ [DEA][C7]. A similar order was also observed in PILs with [DBA] cation in which the decomposition steps of anion with [C5] occurred faster than anion with [C6] and [C7]. Generally, this thermal stability trend can be related to the strong intermolecular forces present in a higher alkyl chain [C7], which requires a high amount of energy to cleave the neighboring bonds. More energy is required to destruct the $\mathrm{C}-\mathrm{C}$ bond as it involves a series of competitive intramolecular and intermolecular process [45,55].

DSC is a thermo-analytical technique that measures the difference in amount of heat required to increase the samples' temperature. The thermogram values of the ammonium-based PILs were recorded as a function of temperature and the extracted data were shown in Table 6. Examples of DSC curves for the ammonium-based PILs synthesized in this study are shown in Figure 5. From the DSC analysis, only PILs with [DEA] cation exhibited a glass transition temperature $\left(\mathrm{T}_{\mathrm{g}}\right)$ under the experimental conditions. This indicates that only PILs with [DEA] cation experience heat flow on heating from amorphous glass to liquid state [5]. $T_{g}$ represents the cohesive energy of the sample. Liquids with low cohesive energies possess $T_{g}$ values which in turn contribute to desirable physiochemical properties such as low viscosity and high ionic conductivity [56]. There is a marginal difference in the $\mathrm{T}_{\mathrm{g}}$ values with respect to the size of the PILs and similar trend is also observed in the literature $[29,56]$. Further analysis of the DSC thermograms indicates that only ammonium-based PILs with [DEA] cation possess crystallization temperature $\left(T_{c}\right)$ with no obvious trend and results show that [DEA][C5] exhibits a $T_{C}$ value of $-58.78^{\circ} \mathrm{C}$. All ammonium-based PILs in this study show the presence of melting temperature $\left(T_{m}\right)$. The $T_{m}$ of PIL is largely depending on the crystal lattice strength of the PIL itself. The poor packing efficiency of the counterions destabilizes the crystal lattice of the PILs and this causes the crystal lattice energy to decrease and consequently contributes to the low $\mathrm{T}_{\mathrm{m}}$ of the PILs [29,57]. Generally, the melting point of PILs with [DEA] cation is higher than that of PILs with [DBA] cation suggesting a better packing of the counterions in the PILs of [DEA] cations. On the other hand, all reported ILs in this paper exhibit low $\mathrm{T}_{\mathrm{m}}$ compared to common ILs such as 3-butyl-1-methylimidazolium chloride, BMIMCl [58-60]. 


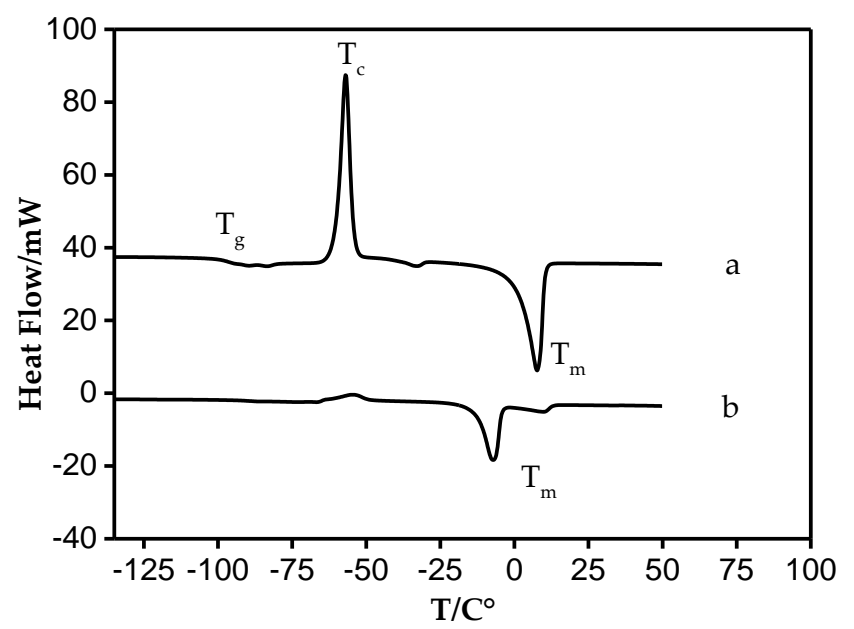

Figure 5. Differential scanning calorimetry (DSC) curves of [DEA][C7] (a) and [DBA][C6] (b) at heating rate of $10^{\circ} \mathrm{C} \cdot \mathrm{min}^{-1}$.

\section{Conclusions}

In this work, six ammonium-based protic ILs with [DEA] and [DBA] cations and combination of three alkyl length of anions (pentyl [C5], hexyl [C6], heptyl [C7]) have been successfully synthesized and characterized. The important thermophysical properties namely density and viscosity were measured from 293.15 to $363.15^{\circ} \mathrm{C}$, while the refractive index was examined from 293.15 to $333.15 \mathrm{~K}$. The water contents of the PILs might have some effects on the measured thermophysical properties. The fitting parameters were proposed for the empirical correlations of density, dynamic viscosity, and refractive index. In addition, the experimental values of densities have been used to calculate the thermal expansion coefficient $\left(\alpha_{\mathrm{p}}\right)$ and molecular volume $\left(\mathrm{V}_{\mathrm{m}}\right)$ of the ammonium-based PILs. The standard entropy $\left(\mathrm{S}^{\circ}\right)$ and lattice potential energy $\left(\mathrm{U}_{\text {pot }}\right)$ have also been calculated using equations available from the literature. Furthermore, the thermal stabilities and behaviors of the ammonium-based PILs were investigated resulting in the determination of thermal decomposition temperature $\left(\mathrm{T}_{\mathrm{d}}\right)$, glass transition temperature $\left(\mathrm{T}_{\mathrm{g}}\right)$, crystallization temperature $\left(\mathrm{T}_{\mathrm{c}}\right)$ and melting point $\left(\mathrm{T}_{\mathrm{m}}\right)$ of the ammonium-based PILs studied. All results indicate the effects of temperature, anion, alkyl chain length and size of the ammonium-based PILs towards the thermophysical properties of the newly synthesized PILs. These results can further be utilized prior to the usage of the PILs in any applications.

Supplementary Materials: The following are available online at http://www.mdpi.com/2227-9717/8/6/742/s1, Table S1: Data used for the validation of equipment for physical property measurements using [HMIM] [Tf $\left.{ }_{2} \mathrm{~N}\right]$ at $\mathrm{T}=298.15 \mathrm{~K}$, Table S2: Density $(\rho)$ values of PILs at temperatures (293.15-363.15) K, Table S3: Dynamic viscosity $(\eta)$ values of PILs at temperatures (293.15-363.15) K, Table S4: Refractive index $\left(n_{\mathrm{D}}\right)$ values of PILs at temperatures (293.15-333.15 K), Figures S1-S12: NMR analysis of the PILs.

Author Contributions: Conceptualization, N.M.Y. and N.H.Z.O.Z.; methodology, N.H.Z.O.Z. and N.M.Y. validation, N.H.Z.O.Z. and A.H.A.R.; formal analysis, N.H.Z.O.Z. and N.M.Y.; resources, N.M.Y. and M.A.B.; data curation, N.M.Y.; writing-original draft preparation, N.H.Z.O.Z. and A.H.A.R.; writing一review and editing, N.M.Y.; supervision, N.M.Y.; project administration, N.M.Y. and M.A.B.; funding acquisition, N.M.Y. All authors have read and agreed to the published version of the manuscript.

Funding: This research was funded by Yayasan Universiti Teknologi PETRONAS-Fundamental Research Grant (YUTP-FRG) (cost centre 015LC0-054) under research project “Design, Synthesis and Evaluation of Protic Ionic Liquids for $\mathrm{CO}_{2}$ Removal from Natural Gas" and the APC was funded by 015LC0-054.

Acknowledgments: Financial assistance and support from Universiti Teknologi PETRONAS and Center of Research in Ionic Liquids (CORIL), UTP are greatly acknowledged.

Conflicts of Interest: The authors declare no conflict of interest. 


\section{References}

1. Endo, T.; Murata, H.; Imanari, M.; Mizushima, N.; Seki, H.; Nishikawa, K. NMR Study of cation dynamics in three crystalline states of 1-butyl-3-methylimidazolium hexafluorophosphate exhibiting crystal polymorphism. J. Phys. Chem. B 2012, 116, 3780-3788. [CrossRef]

2. Smith, J.A.; Webber, G.B.; Warr, G.G.; Atkin, R. Rheology of protic ionic liquids and their mixtures. J. Phys. Chem. B 2013, 117, 13930-13935. [CrossRef]

3. Patra, R.N.; Gardas, R.L. Effect of nitro groups on desulfurization efficiency of benzyl-substituted imidiazolium-based ionic liquids: Experimental and computational approach. Energy Fuels 2019, 33, 7659-7666. [CrossRef]

4. Singh, V.; Sharma, G.; Gardas, R.L. Thermodynamic and ultrasonic properties of ascorbic acid in aqueous protic ionic liquid solutions. PLoS ONE 2015, 10, e0126091. [CrossRef] [PubMed]

5. Sarkar, A.; Sharma, G.; Singh, D.; Gardas, R.L. Effect of anion on thermophysical properties of N,N-diethanolammonium based protic ionic liquids. J. Mol. Liq. 2017, 242, 249-254. [CrossRef]

6. Baicha, Z.; Salar-García, M.J.; Ortiz-Martínez, V.M.; Hernández-Fernández, F.J.; de los Ríos, A.P.; Maqueda Marín, D.P.; Collado, J.A.; Tomás-Alonso, F.; El Mahi, M. On the selective transport of nutrients through polymer inclusion membranes based on ionic liquids. Processes 2019, 7, 544. [CrossRef]

7. Abejón, R.; Rabadán, J.; Lanza, S.; Abejón, A.; Garea, A.; Irabien, A. Supported ionic liquid membranes for separation of lignin aqueous solutions. Processes 2018, 6, 143. [CrossRef]

8. Taimoor, A.A.; Al-Shahrani, S.; Muhammad, A. Ionic liquid (1-butyl-3-metylimidazolium methane sulphonate) corrosion and energy analysis for high pressure $\mathrm{CO}_{2}$ absorption process. Processes 2018, 6, 45. [CrossRef]

9. Bogdanov, M.G.; Svinyarov, I. Distribution of N-methylimidazole in ionic liquids/organic solvents systems. Processes 2017, 5, 52. [CrossRef]

10. Keremedchieva, R.; Svinyarov, I.; Bogdanov, M.G. Ionic Liquid-Based Aqueous Biphasic Systems-A facile approach for ionic liquid regeneration from crude plant extracts. Processes 2015, 3, 769-778. [CrossRef]

11. Ahmat, X.; Ablajan, K.; Shinozaki, H. Furans-Maleimides Diels-Alder reactions in protic ionic liquid. Chem. Res. Chin. Univ. 2009, 25, 161-168.

12. Mancini, P.M.E.; Ormachea, C.M.; Rosa, C.D.D.; Kneeteman, M.N.; Domingo, L.R. Protic and nonprotic ionic liquids in polar Diels-Alder reactions using properly substituted heterocycles and carbocycles as dienophiles. A DFT study. In Ionic Liquids: New Aspects for the Future; IntechOpen: London, UK, 2013; Volume 9, pp. 691-695.

13. Rosa, C.D.; Ormachea, C.; Kneeteman, M.N.; Adam, C.; Mancini, P.M.E. Diels-Alder reactions of $\mathrm{N}$-tosylpirroles developed in protic ionic liquids. Theoretical studies using DFT methods. Tetrahedron Lett. 2011, 52, 6754-6757. [CrossRef]

14. Greaves, T.L.; Drummond, C.J. Protic Ionic Liquids: Evolving structure-property relationships and expanding applications. Chem. Rev. 2015, 115, 11379-11448. [CrossRef] [PubMed]

15. Miran, M.S.; Yasuda, T.; Susan, M.A.B.H.; Dokko, K.; Watanabe, M. Binary protic ionic liquid mixtures as a proton conductor: High fuel cell reaction activity and facile proton transport. J. Phys. Chem. C 2014, 118, 27631-27639. [CrossRef]

16. Lee, S.-Y.; Ogawa, A.; Kanno, M.; Nakamoto, H.; Yasuda, T.; Watanabe, M. Nonhumidified intermediate temperature fuel cells using protic ionic liquids. J. Am. Chem. Soc. 2010, 132, 9764-9773. [CrossRef]

17. Greaves, T.L.; Drummond, C.J. Protic ionic liquids: Properties and applications. Chem. Rev. 2008, 108, 206-237. [CrossRef]

18. Hirao, M.; Sugimoto, H.; Ohno, H. Preparation of novel room-temperature molten salts by neutralization of amines. J. Electrochem. Soc. 2000, 147, 4168-4172. [CrossRef]

19. MacFarlane, D.R.; Forsyth, M.; Izgorodina, E.I.; Abbott, A.P.; Annat, G.; Fraser, K. On the concept of ionicity in ionic liquids. Phys. Chem. Chem. Phys. 2009, 11, 4962-4967. [CrossRef]

20. Shen, M.; Zhang, Y.; Chen, K.; Che, S.; Yao, J.; Li, H. Ionicity if protic ionic liquid: Quantitative measurement by spectroscopic methods. J. Phys. Chem. B 2017, 121, 1372-1376. [CrossRef]

21. MacFarlane, D.R.; Seddon, K.R. Ionic liquids-Progress on the fundamental issues. Aust. J. Chem. 2007, 60, 3-5. [CrossRef] 
22. Yunus, N.M.; Halim, N.H.; Wilfred, C.D.; Murugesan, T.; Lim, J.W.; Show, P.L. Thermophysical properties and $\mathrm{CO}_{2}$ absorption of ammonium-based protic ionic liquids containing acetate and butyrate anions. Processes 2019, 7, 820. [CrossRef]

23. Petrović, V.P.; Simijonović, D.; Petrović, Z.D.; Marković, S. Formation of a vanillic Mannich base-Theoretical study. Chem. Pap. 2015, 69, 1244-1252. [CrossRef]

24. Khan, A.; Lu, X.; Aldous, L.; Zhao, C. oxygen reduction reaction in room temperature protic ionic liquids. J. Phys. Chem. C 2013, 117, 18334-18342. [CrossRef]

25. Kondratenko, Y.A.; Nyanikova, G.G.; Molchanova, K.V.; Kochina, T.A. Characteristics of protic ionic liquids based on triethanolammonium salts of biologically active carboxylic acids and their impact on the growth properties of the Rhizopus oryzae fungus. Glass Phys. Chem. 2017, 43, 445-451. [CrossRef]

26. Yi, L.; Feng, J.; Li, W.-Y. Separation of phenolic compounds from coal liquefaction oil by choline chloride-glycerol deep eutectic solvents. Energy Procedia 2019, 158, 5169-5174. [CrossRef]

27. Lu, J.-G.; Li, X.; Zhao, Y.-X.; Ma, H.-L.; Wang, L.-F.; Wang, X.-Y.; Yu, Y.-F.; Shen, T.-Y.; Xu, H.; Zhang, Y.-T. CO 2 capture by ionic liquid membrane absorption for reduction of emissions of greenhouse gas. Environ. Chem. Lett. 2019, 17, 1031-1038. [CrossRef]

28. Liu, Q.; Mou, L.; Zheng, Q.; Xia, Q. Thermodynamic properties of ionic liquids. In Progress and Developments in Ionic Liquids; IntechOpen: London, UK, 2017. [CrossRef]

29. Shen, Y.; Kennedy, D.F.; Greaves, T.L.; Weerawardena, A.; Mulder, R.J.; Kirby, N.; Song, G.; Drummond, C.J. Protic ionic liquids with fluorous anions: Physicochemical properties and self-assembly nanostructure. Phys. Chem. Chem. Phys. 2012, 14, 7981-7992. [CrossRef]

30. Akbari, F.; Alavianmehr, M.M.; Behjatmanesh Ardakani, R.; Mohammad-Aghaie, D. Thermophysical properties of ionic liquids and their mixtures from a new equation of state. Ionics 2018, 24, 1357-1369. [CrossRef]

31. Vijayraghavan, R.; Pas, S.J.; Izgorodina, E.I.; MacFarlane, D.R. Diamino protic ionic liquids for $\mathrm{CO}_{2}$ capture. Phys. Chem. Chem. Phys. 2013, 15, 19994-19999. [CrossRef]

32. Kurnia, K.A.; Harris, F.; Wilfred, C.D.; Abdul Mutalib, M.I.; Murugesan, T. Thermodynamic properties of $\mathrm{CO}_{2}$ absorption in hydroxyl ammonium ionic liquids at pressures of (100-1600) kPa. J. Chem. Thermodyn. 2009, 41, 1069-1073. [CrossRef]

33. Guo, H.; Smith, T.W.; Iglesias, P. The study of hexanoate-based protic ionic liquids used as lubricants in steel-steel contact. J. Mol. Liq. 2020, 299, 112208. [CrossRef]

34. Kopczyńskia, K.; Gabryelczyka, A.; Baraniaka, M.; Łegosza, B.; Pernaka, J.; Jankowskab, E.; Rzeszutekc, W.; Kędziorc, P.; Lota, G. Positive electrode material in lead-acid car battery modified by protic ammonium ionic liquid. J. Energy Storage 2019, 26, 100996. [CrossRef]

35. Mayrand-Provencher, L.; Lin, S.; Lazzerini, D.; Rochefort, D. Pyridinium-based protic ionic liquids as electrolytes for $\mathrm{RuO}_{2}$ electrochemical capacitors. J. Power Sources 2010, 195, 5114-5121. [CrossRef]

36. Iglesias, M.; Gonzalez-Olmosa, R.; Cota, I.; Medina, F. Brønsted ionic liquids: Study of physico-chemical properties and catalytic activity in aldol condensations. Chem. Eng. J. 2010, 162, 802-808. [CrossRef]

37. Chen, Y.; Cao, Y.; Lu, X.; Zhao, C.; Yan, C.; Mu, T. Water sorption in protic ionic liquids: Correlation between hygroscopicity and polarity. New J. Chem. 2013, 37, 1959-1967. [CrossRef]

38. Freire, M.G.; Santos, L.M.N.B.F.; Fernandes, A.M.; Coutinho, J.A.P.; Marrucho, I.M. An overview of the mutual solubilities of water-imidazolium-based ionic liquids systems. Fluid Phase Equilibria 2007, 261, 449-454. [CrossRef]

39. Seddon, K.; Stark, A.; Torres, M.-J. Influence of Chloride, Water, and Organic Solvents on the Physical Properties of Ionic Liquids. Pure Appl. Chem. 2000, 72, 2275-2287. [CrossRef]

40. Yunus, N.M.; Abdul Mutalib, M.I.; Man, Z.; Bustam, M.A.; Murugesan, T. Thermophysical properties of 1-alkylpyridinum bis(trifluoromethylsulfonyl)imide ionic liquids. J. Chem. Thermodyn. 2010, 42, 491-495. [CrossRef]

41. Gusain, R.; Panda, S.; Bakshi, P.S.; Gardas, R.L.; Khatri, O.P. Thermophysical properties of trioctylalkylammonium bis(salicylato)borate ionic liquids: Effect of alkyl chain length. J. Mol. Liq. 2018, 269, 540-546. [CrossRef]

42. Wu, B.; Yamashita, Y.; Endo, T.; Takahashi, K.; Castner, E.W. Structure and dynamics of ionic liquids: Trimethylsilylpropyl-substituted cations and bis(sulfonyl)amide anions. J. Chem. Phys. 2016, 145, 244506. [CrossRef] 
43. Pinto, R.R.; Mattedi, S.; Aznar, M. Synthesis and physical properties of three protic ionic liquids with the ethylammonium cation. Chem. Eng. Trans. 2015, 43, 1165-1170.

44. Chennuri, B.K.; Gardas, R.L. Measurement and correlation for the thermophysical properties of hydroxyethyl ammonium based protic ionic liquids: Effect of temperature and alkyl chain length on anion. Fluid Phase Equilibria 2016, 427, 282-290. [CrossRef]

45. Keshapolla, D.; Srinivasarao, K.; Gardas, R.L. Influence of temperature and alkyl chain length on physicochemical properties of trihexyl- and trioctylammonium based protic ionic liquids. J. Chem. Thermodyn. 2019, 133, 170-180. [CrossRef]

46. Zhang, X.U.; Faber, D.J.; Post, A.L.; van Leeuwen, T.G.; Sterenborg, H.J.C.M. Refractive index measurement using single fiber reflectance spectroscopy. J. Biophotonics 2019, 12, 701-713. [CrossRef] [PubMed]

47. Soave, G. Equilibrium constants from a modified Redlich-Kwong equation of state. Chem. Eng. Sci. 1972, 27, 1197-1203. [CrossRef]

48. Singh, D.; Gardas, R.L. Influence of cation size on the ionicity, fluidity, and physiochemical properties of 1,2,4-triazolium based ionic liquids. J. Phys. Chem. B 2016, 120, 4834-4842. [CrossRef]

49. Zec, N.; Vraneš, M.; Bešter-Rogač, M.; Trtić-Petrović, T.; Dimitrijević, A.; Čobanov, I.; Gadžurić, S. Influence of the alkyl chain length on densities and volumetric properties of 1,3-dialkylimidazolium bromide ionic liquids and their aqueous solutions. J. Chem. Thermodyn. 2018, 121, 72-78. [CrossRef]

50. Tariq, M.; Forte, P.A.S.; Gomes, M.F.C.; Lopes, J.N.C.; Rebelo, L.P.N. Densities and refractive indices of imidazolium- and phosphonium-based ionic liquids: Effect of temperature, alkyl chain length, and anion. J. Chem. Thermodyn. 2009, 41, 790-798. [CrossRef]

51. Liu, Q.-S.; Yang, M.; Li, P.-P.; Sun, S.-S.; Welz-Biermann, U.; Tan, Z.-C.; Zhang, Q.-G. Physicochemical properties of ionic liquids $\left[\mathrm{C}_{3}\right.$ py][⿰NTf $\left.{ }_{2}\right]$ and $\left[\mathrm{C}_{6}\right.$ py] $\left[\mathrm{NTf}_{2}\right]$. J. Chem. Eng. Data 2011, 56, 4094-4101. [CrossRef]

52. Liu, Q.-S.; Li, P.-P.; Welz-Biermann, U.; Chen, J.; Liu, X.-X. Density, dynamic viscosity, and electrical conductivity of pyridinium-based hydrophobic ionic liquids. J. Chem. Thermodyn. 2013, 66, 88-94. [CrossRef]

53. Liu, Q.-S.; Li, Z.; Welz-Biermann, U.; Li, C.-P.; Liu, X.-X. Thermodynamic properties of a new hydrophobic amide-based task-specific ionic liquid [EimCH$\left.{ }_{2} \mathrm{CONHBu}\right]\left[\mathrm{NTf}_{2}\right]$. J. Chem. Eng. Data 2013, 58, 93-98. [CrossRef]

54. Glasser, L. Lattice and phase transition thermodynamics of ionic liquids. Thermochim. Acta 2004, 421, 87-93. [CrossRef]

55. Bandrés, I.; Royo, F.M.; Gascón, I.; Castro, M.; Lafuente, C. Anion influence on thermophysical properties of ionic liquids: 1-butylpyridinium tetrafluoroborate and 1-butylpyridinium triflate. J. Phys. Chem. B 2010, 114, 3601-3607. [CrossRef] [PubMed]

56. Greaves, T.L.; Weerawardena, A.; Fong, C.; Krodkiewska, I.; Drummond, C.J. Protic ionic liquids: solvents with tunable phase behavior and physicochemical properties. J. Phys. Chem. B 2006, 110, 22479-22487. [CrossRef]

57. Cai, G.; Yang, S.; Zhou, Q.; Liu, L.; Lu, X.; Xu, J.; Zhang, S. Physicochemical properties of various 2-hydroxyethylammonium sulfonate -based protic ionic liquids and their potential application in hydrodeoxygenation. Front. Chem. 2019, 7, 196. [CrossRef]

58. Dharaskar, S.A.; Wasewar, K.L.; Varma, M.N.; Shende, D.Z.; Yoo, C.K. Synthesis, characterization and application of 1-butyl-3-methylimidazolium tetrafluoroborate for extractive desulfurization of liquid fuel. Arab. J. Chem. 2016, 9, 578-587. [CrossRef]

59. Efimova, A.; Hubrig, G.; Schmidt, P. Thermal stability and crystallization behavior of imidazolium halide ionic liquids. Thermochim. Acta 2013, 573, 162-169. [CrossRef]

60. Dharaskar, S.A.; Wasewar, K.L.; Varma, M.N.; Shende, D.Z.; Yoo, C.K. Deep removal of sulfur from model liquid fuels using 1-butyl-3-methylimidazolium chloride. Procedia Eng. 2013, 51, 416-422. [CrossRef]

(C) 2020 by the authors. Licensee MDPI, Basel, Switzerland. This article is an open access article distributed under the terms and conditions of the Creative Commons Attribution (CC BY) license (http://creativecommons.org/licenses/by/4.0/). 